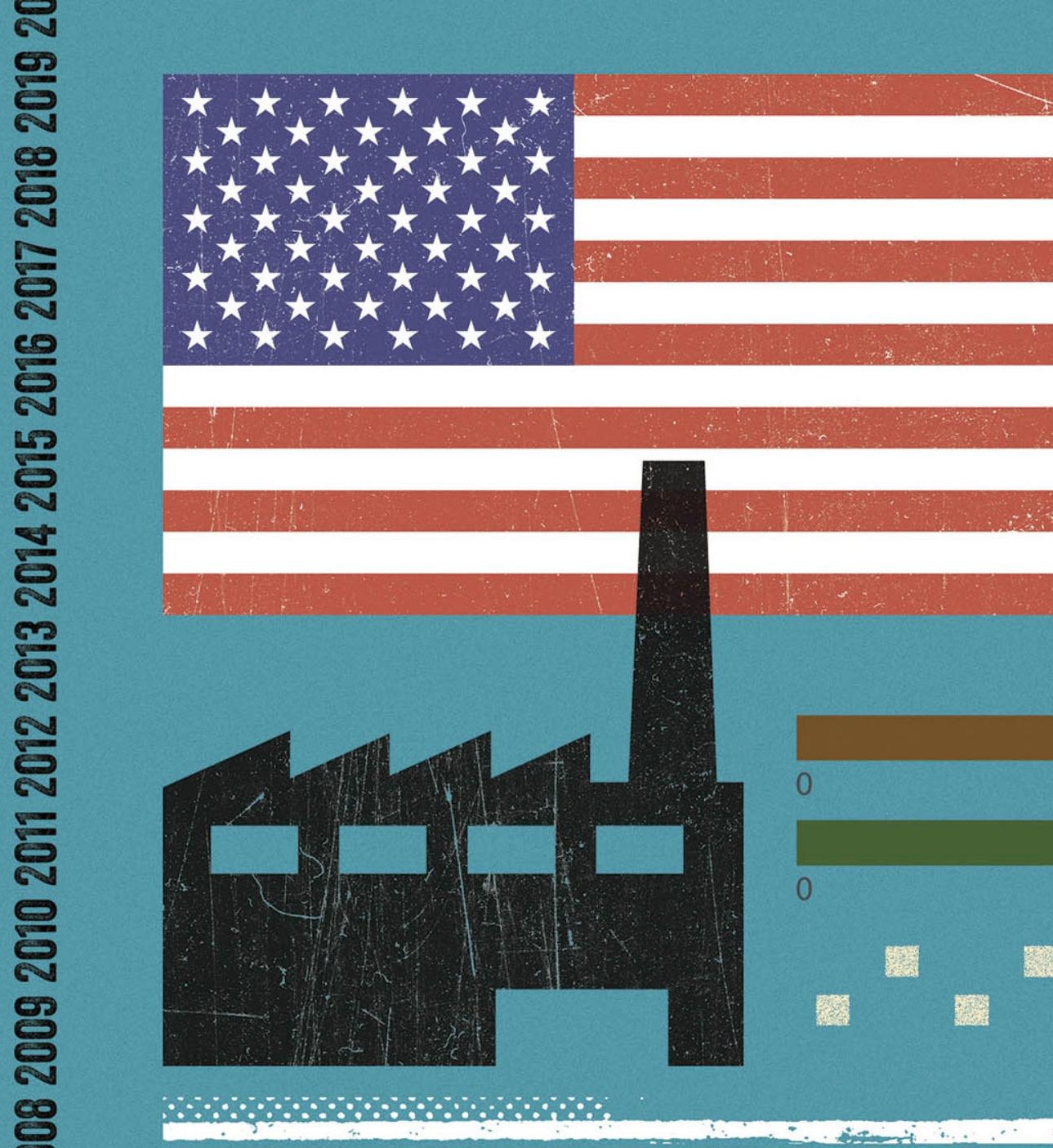




\title{
The Origin of Regulatory Agencies in the United States: A Case of Institutional Change
}

\author{
A Origem dass Agênciass Reguladoras nos \\ Estados Unidos: Um Caso de Mudança Insti- \\ tucional
}

Paula Silva de Carvalho*

\begin{abstract}
This paper seeks to detail the process that culminated in the creation of the first regulatory agencies and analyzes this process through the lens of Douglass North's (1990) theory of institutional change. The first regulatory agency with the power to regulate rates emerged in 1873 in the state of Illinois in the United States amid the conflict between farmers and railroads around rail fares. The analysis of this historical process indicates that North's theory fits well in explaining the rise of the regulatory agencies because the perception regarding relative prices, which is underlined by this author as the main motivation for institutional change, was effectively the major factor behind the emergence of this model of institutional arrangement.
\end{abstract}

Keywords: regulatory agencies, institutional change, Douglass North.

JEL Classification: N41

\begin{abstract}
Resumo
Este artigo busca detalhar o processo que culminou na criação das primeiras agências reguladorase o analisa à luz da teoria de mudança institucional de Douglass North (1990). A primeira agência reguladora com poder para regular tarifas surgiu em 1873 no estado de Illinois nos Estados Unidos em meio ao conflito entre agricultores e ferrovias em torno das tarifas ferroviárias. A análise desse processo histórico indica que a teoria de mudança institucional de North se encaixa bem para explicar o surgimento das agências reguladoras, pois a percepção sobre preços relativos, que é ressaltada por este autor como a principal motivação para a mudança institucional, foi efetivamente o grande fator por trás da emergência deste modelo de arranjo institucional.
\end{abstract}

Palavras-chave: agências reguladoras, mudança institucional, Douglass North.

\footnotetext{
* Programa de Pós-Graduação em Políticas Públicas, Estratégias e Desenvolvimento; Universidade Federal do Rio de Janeiro (UFRJ). E-mail: paulacarv@yahoo.com. The author is grateful for the comments of Ronaldo Fiani. Any errors and omissions are the sole responsibility of the author.
} 


\section{INTRODUCTION}

Regulatory agencies that have the power to regulate rates are a model of formal institutional arrangement that is currently widely used in public administration. Their origin, however, dates back to the nineteenth century. The first regulatory agency with the power to regulate tariffs was established in 1873 in the state of Illinois, United States, amid the conflict between farmers and railroads around rail fares. Indeed, state regulatory agencies emerged before the creation of the Interstate Commerce Commission in 1887, which was the first federal regulatory agency in the United States. However, this period of state regulation is largely neglected in the literature, which usually gives the history of the regulatory agencies from the federal agency context.

Therefore, the general objective of this paper is to offer a broader understanding of the origin of the regulatory agencies since the history of economic institutions and organizations is key to comprehending the dynamics of their evolution. For this purpose, this article seeks to provide a detailed account of the process that culminated in the creation of the first state agencies in the United States, complementing the description presented in Kanazawa \& Noll (1994). Additional historical research was conducted based on secondary sources, especially American publications of the late nineteenth century and early twentieth century such as Clark (1891), McLean (1900b, 1900a), Detrick (1903) and Buck (1913). The intention of using these historical sources was to obtain more detailed information and to capture the debate in the period that followed the emergence of the agencies.

A second objective and main contribution of this paper is to give a theoretical frame to the institutional change process that gave rise to the first regulatory agency. For this purpose, Douglass North's (1990) approach to institutional change was chosen as a theoretical framework that is potentially suitable for explaining the emergence of the model of regulatory agencies. The analysis indicates that North's (1990) theory fits well in explaining the process that gave rise to the regulatory agencies because the perception regarding relative prices, which is underlined by this author as the main motivation for institutional change, was effectively the major factor behind the emergence of these agencies.

The article contains three sections. The first presents the theory of institutional change developed by Douglass North (1990). The second section describes the historical context that led to the creation of the first regulatory agencies. Finally, the third section analyzes the creation of the regulatory agencies according to North's theory.

\section{DOUGLASS NORTH'S APPROACH ${ }^{1}$}

According to North (1990), institutions are constraints devised by humans that structure human interactions. Thus, institutions serve as a guide for human 
interactions, reducing uncertainty and providing incentives for exchanges between people (North, 1990, p.3).

However, while stating that the main role of institutions in a society is to reduce uncertainty in human interactions (North, 1990, p.6), North points out that institutions are not created to be socially efficient. In his view, institutions are largely constructed on the basis of private welfare interests, rather than the aggregate societal welfare (North, 1990, p.48):

Institutions are not necessarily or even usually created to be socially efficient; rather they, or at least the formal rules, are created to serve the interests of those with the bargaining power to devise new rules. (North, 1990, p.16)

Therefore, such institutions, which are not necessarily efficient, provide the incentive structure for the development of organizations, since these are "purposive entities designed by their creators to maximize wealth, income, or other objectives defined by the opportunities afforded by the institutional structure of the society" (North, 1990, p.73). In other words, organizations are created to take advantage of the opportunities provided by a given institutional structure. This relationship between organizations and institutional structure explains why some organizations develop in a society instead of others.

To the extent, however, that organizations develop and evolve in a search for maximizing their goals, they promote changes in the institutional structure. Thereafter, in North's (1990) approach, entrepreneurs and their organizations are the main agents of institutional change and the interaction between institutions and organizations shapes the direction of institutional change (North, 1990, p.7).

To explain the behavior of individuals and provide the micro fundaments for his theory, North (1990) adopts the assumptions of bounded rationality and incomplete information. He refutes the behavioral assumptions of rational choice theory, arguing that this theory is deficient for treating the following two aspects of human behavior: the motivation for individuals' choices, and the way they decipher the environment. On the question of motivation, deficiency occurs because, in addition to the wealth maximization embodied in neoclassical models, individuals' choices may also be motivated by altruism, self-imposed standards of conduct and ideologies. In relation to environmental deciphering, the rational choice theory does not take into account that cognitive limitations and the complexity of problems cause individuals to decipher the environment by processing information through pre-existing mental constructs (North, 1990, p.20). Thus, North rejects the idea that individuals have cognitive systems that provide true models of the universes in which they make their choices. Furthermore, as the information received by individuals is incomplete, these models do not tend to converge to the true models.

North thus emphasizes the crucial role of the subjective perceptions of the agents. In his view, the sources of action of the institutional change process are the 
opportunities perceived by the entrepreneurs, which result from both external changes in the environment as well as internal changes within the entrepreneurs. Among the external sources are objective changes in relative prices and changes in taste. The internal sources, in turn, would be the acquisition of learning and skills that lead entrepreneurs to develop new mental models to decipher the environment, altering the perceived relative prices of their potential choices (North, 1993, p.4-5) ${ }^{2}$.

The excerpt below, taken from North (1993), provides an excellent summary of his reasoning:

Thus entrepreneurs who perceive themselves and their organizations as relative (or absolute) losers in economic exchange as a consequence of the existing structure of relative prices can turn to the political process to right their perceived wrongs by altering that relative price structure. In any case it is the perceptions of the entrepreneur - correct or incorrect - that are the sources of action. (North, 1993, p.37)

It is clear, therefore, that, in North's view, the process of institutional change is motivated by the perceptions of entrepreneurs, regardless of objective facts. Consequently, objective changes in relative prices only induce institutional change if they are perceived as such by entrepreneurs. Similarly, institutional changes could occur without an objective change in relative prices if learning processes make the entrepreneurs view the relative prices of their potential choices as changing.

When referring to institutional changes, North notes that they may occur as a result of changes in informal institutions, changes in formal institutions or changes in the enforcement mechanisms (North, 1990, p.6).

To North, informal institutions are codes of conduct, norms of behavior and conventions that are socially transmitted and are part of the culture of a society (North, 1990, p.37). Changes in informal institutions are not necessarily intentional, given that informal rules may evolve without any specific purposeful activity on the part of individuals and organizations (North, 1990, p.87). In this case, a change in relative prices or in tastes leads to the gradual erosion of the rule and its replacement by another rule.

On the other hand, formal institutions are rules created intentionally by human beings (North, 1990, p.4) and rely on the coercive power of the state to enforce them. The need for this type of rule is found in more complex societies, in which the fact that trade is impersonal and nonrepetitive increases the return for opportunistic behavior, making the support of the state essential to enable trade (North, 1990, p.35). It should be noted here that while formal institutions may arise to replace informal institutions, North emphasizes the complementarity between the two types of institutions. In his view, the main role of informal constraints is to modify, supplement or extend the formal rules (North, 1990, p.87).

In the case of formal institutions, changes occur through the political process and, therefore, require a considerable application of resources. In this case, the perception of changes in relative prices does not necessarily lead to institutional changes and may simply lead to a reformulation of contracts within the framework of the existing rules. 
Everything depends on the estimated costs and benefits of promoting change (North, 1990, p.87). Organizations with sufficient bargaining power will strive to change formal rules when the estimated return from maximizing in that direction exceeds the return from investing within the existing restrictions (North, 1990, p.79).

North (1990, p.87) also notes that, insofar as the act to influence rules and their enforcement bring great rewards, it will pay for agents to create intermediary organizations between economic organizations and government agencies (for example, trade associations, lobby groups and political action committees) to realize the potential gains of political change. The greater the proportion of resources affected by government decisions, the more resources will be devoted to this type of organization that, on the one hand, seeks to promote institutional changes that benefit its members and, on the other, seeks to avoid those that may harm them.

Hence, according to North (1990), changes in informal institutions are not necessarily intentional and occur at a slower pace. Changes in formal institutions, in turn, occur when the subjective perception of an organization about the change benefits leads it to dedicate resources for this purpose. Thus, the initiative to change the rules depends on the agents' estimation of the costs and benefits. The greater the rewards envisioned, the greater the resources dedicated.

Furthermore, North highlights two points involving the interaction between formal and informal rules in the institutional change processes. The first point is that, given the complementarity between formal and informal institutions, changes in formal rules trigger changes in informal rules. This happens because a change in formal rules or in their enforcement causes disequilibrium in the set of constraints in force. More specifically, changes in the formal rule sphere affect the transaction costs leading to the development of new conventions or standards, so that a new informal equilibrium will evolve gradually after a change in the formal rules (North, 1990, p.87).

Second, North highlights the persistent nature of informal rules, which makes it not always possible to adopt formal rules under the deliberate intention of replacing the informal rules in force. The attempt to replace informal rules with formal rules does not always succeed because the informal constraints contain persistent cultural traits and change at a different pace from the formal rules (North, 1990, p.87). As an example, the author cites the fact that revolutionary acts may change the formal rules but not the informal ones, creating a tension between the informal constraints and the new formal rules as many are inconsistent with each other (North, 1990, p. 91).

Thus, in view of this persistent nature of informal rules, North (1990, p.89) emphasizes the incremental nature of the institutional change process. Although wars, revolutions and natural disasters are sources of radical changes in the formal rules, the process of institutional change is predominantly incremental.

Finally, North (1990, p.10) notes that the incremental nature of the process of institutional change and the imperfect way in which the actors interpret the environment are responsible for making the institutional change path dependent. In 
this context, the choices of the present and the future are shaped by the past and, consequently, historical analysis becomes relevant.

This theory of institutional change developed by North (1990) provides a useful theoretical framework for the analysis of the rise of regulatory agencies presented in the next section.

\section{THE RISE OF REGULATORY AGENCIES IN THE UNITED STATES}

To understand the process that resulted in the creation of the first regulatory agencies in the United States, one must keep in mind that the American federal system grants considerable autonomy to the states in creating statewide laws and enforcement processes. This section is divided into two subsections. The first describes the process of the development of the railway network in the United States, while the second describes the evolution of state-level railroad regulation before the passage of federal railroad regulation in 1887.

\section{The Development of the Railway Network in the United States}

An outstanding feature of the development of the US railway network is that it occurred mostly under private ownership. However, this does not imply that the principle of laissez faire predominated. Indeed, US railroads emerged and expanded under a system involving the public capitalization of private companies (Dowd and Dobbin, 2001).

The construction of the North American railway network began circa 1830 and had different phases. Clark (1891) distinguishes the following three stages: the period of "enthusiastic construction", from 1830 to 1850; the period of "bitter competition", from 1850 to 1870 ; and the period of "extensive combination", from 1870 to 1890.

In the first period, between 1830 and 1850, the state on all its levels actively participated in the expansion of the railway network with actions that ranged from donations of federal lands to the granting of subsidies by local governments. The main purpose was to promote the development of the interior of the United States given that the colonization of land in the Midwest ${ }^{3}$ of the country depended on reliable and inexpensive transportation to take the primary products produced there to the cities on the East Coast (Kanazawa and Noll, 1994, p.19).

The engagement of state and local governments, however, was greater than that of the federal government. First, because in this early stage most railways were intrastate, the task of granting operating licenses to railway companies was delegated to the state legislatures (McLean, 1900a, p.151). Second, this limited role played by the federal government was implied by contemporary notions of democracy; it was feared that the involvement of the federal government in commercial activities would lead to a power concentration that would undermine the democratic system (Dowd and 
Dobbin, 2001, p.65). In this context, the states had the task of managing the land grants from the federal government to the railroads and gathering rights of way (Kanazawa and Noll, 1994, p.19).

Given the enthusiasm for railways, some states undertook construction under direct public administration, as was the case in Pennsylvania, Ohio, Illinois and Michigan. The motivation for these ventures was the belief that states could obtain capital on better terms than private enterprises. The results of these experiments, however, were disastrous and a time of failure occurred circa 1850. The states then moved to the other extreme after 1850 with the insertion of clauses in their constitutions that limited their power of indebtedness (McLean, 1900b, p.352). The Michigan constitution of 1850, in particular, went further and banned all future connection of this state with the construction of railways or any other system of internal improvement (Clark, 1891, p.15).

The second period, which ranges from 1850 to 1870 , was marked by the emergence of competition between railways. Until the $1860 \mathrm{~s}$, most rail traffic was local and had little or no competition, thus leading to high rates. However, after 1863 several short distance lines were interconnected, giving rise to parallel long-distance lines. The competition for traffic on long-haul routes between major cities intensified, leading to price wars between the railroads (Sanders, 1999 p.183). In addition, the linking of New York City to the Great Lakes began a fierce competition between rail and waterway transportation, which, until then, enjoyed an uninterrupted prosperity (Clark, 1891, p.16).

These price wars, however, did not reach small and remote rail users, as was the case of most farmers. They were not able to receive the discount rates available to large shippers, found themselves far away from the main terminals, did not have access to water transportation and usually were served by only one rail line, remaining at the mercy of railroad monopolies. Indeed, the emergence of competition in long distance lines worsened the situation of farmers, as the "captive" users had to subsidize the price cuts offered to users in more advantageous competitive situations (Sanders, 1999 p.183). This was a major reason for the conflict between farmers and railroads that culminated in the creation of the regulatory agencies, as will be discussed below.

Finally, in the period from 1870 to 1890 , the railroads responded to the growing competition for long distance consumers through the formation of cartels. The first and perhaps most successful of these projects was the lowa pool. Three railroads competing for traffic between Chicago and Omaha formally agreed in 1870 to share the business to end the competition. Informally their monopoly territories were, in general, respected (Sanders, 1999 p.183).

These periods that Clark (1891) distinguished for the construction and operation of railways corresponded to different stages of regulation to be discussed in the next section. 


\section{The State Regulation of Railroads}

Clark (1891) divides the state regulatory policy of railroads into three phases corresponding to the railway construction stages as follows: the period of "freedom from interference", from 1830 to 1850; the period of "general laws and statutes", from 1850 to 1870 ; and the period of "state interference or control through commissions", from 1870 to 1890 .

In the years of "freedom from interference", both in the US and in England, it was believed that the railroad company would be under the control of universal competition and the limitations of the competitive principle arising from large investment in fixed assets were not perceived (McLean, 1900b, p.352). In the words of Adams (1878, p.1256): "Competition made the price of flour and cloth and shoes equal and reasonable: why should it make fares and freights unequal and unreasonable?"

Thus, given this belief that the competition between railroads would solve all problems, especially those related to abusive charges, the concern at this time was for the construction of more railways. Any proposed legislation for the regulation of railroads was declared harmful and unfair. Consequently, in this period there was little or no restrictive legislation. In fact, laws passed at the time aimed at encouraging construction as there were fears that the railways would not be built rapidly enough (Clark, 1891).

It was only in the 1850s, the beginning of the second period, that there began to appear changes in state laws to establish rules for the concession and operation of railways. Among the factors that motivated the change from the nonregulation of the previous period were the excessive indebtedness of states and corruption scandals (Kanazawa and Noll, 1994, p.20). The latter ranged from the granting of free tickets to legislators, judges and their families to influence decisions, to a subtler form of bribery in which valuable actions were transferred to legislators at prices far below their market value (Buck, 1913, p. 13).

At this time, there also emerged the bureaucratic bodies considered the precursors of regulatory agencies. One of these bodies was the Michigan Board of Control created in 1857, which was composed of the governor and six appointed members. Although this council was created with the purpose of negotiating the terms of land grants, its structure and procedures were clear precursors of economic regulation bodies (Kanazawa and Noll, 1994, p.20).

Other precursors of regulatory bodies that emerged at this time were the commissions set up in the eastern states to supervise railroad safety. These commissions were administrative bodies subordinated to state legislatures with the function of overseeing the railroad companies under the rubric of public safety. The movement began in 1844 with the law that established such a commission in New Hampshire and continued with the establishment of this type of commissions in Connecticut in 1853, Vermont in 1855 and Maine in 1858 (McLean, 1900b, p.356). 
Efforts at a more direct state interference in the railway business, however, encountered legal obstacles because the courts saw the agreements between the railroads and the states as contracts, which thus could not be changed unilaterally by the state through the passing of new laws. This argument was based on the Supreme Court's Dartmouth College decision in 1819, which determined that a corporate license was a contract between the corporation and the state, and its weakening violated the US Constitution. The only situation in which the courts authorized laws that changed the initial agreements was when either the operating licenses granted to the railroad companies or the state constitutions contained a clause that explicitly allowed the review of the licenses. For this reason, several states decided to include clauses that reserved to their legislatures the power to regulate corporations (Kanazawa and Noll, 1994, p.16-17).

Clark (1891) points out that, overall, as the system of railways that began construction in the previous period became operational, which primarily occurred on the east coast, it was soon realized that competition would not limit the power of railroad corporations. Indeed, the fact that several states had declared in their constitutions that state legislatures should have full power to act in matters relating to railroads clearly revealed that the need for somehow constraining the railroads had increased.

The 1870s mark the beginning of the period of "states interference or control through commissions". The popular pressure emanating especially from farmers through the Granger movement was emblematic of this change in the policy of railroad regulation. The Granger movement consisted of an alliance of American farmers created in 1867 (under the formal name of the Patrons of Husbandry), which reached its peak membership in 1875. Although it was also active in other areas of farmers concerns ${ }^{4}$, the best known of its causes was the fight against monopoly abuses exercised by the railroad companies, attempting to subjugate them to the control of the state (Buck, 1913, p.123). Among the complaints of farmers were the previously mentioned cases of corruption involving the railroads, the charging of abusive rates and the practice of brutal discrimination in rate-setting.

This issue of rate discrimination was particularly relevant because it favored only the largest and most urban shippers. Farmers in rural communities paid relatively more to transport their production to the nearest large city than in the longer part of the trip to the port. As mentioned above, this was because, at the end of the 1860s, grain transportation between major cities in the Midwest and the East Coast ports was competitive, resulting in lower rates. However, most rural communities had no access to water transportation and were served by only one railway, which allowed the railroads to exercise their monopoly power in these secondary routes. At the time, the only alternative for farmers who felt harmed by these monopolistic practices was to resort to the regular courts, opening proceedings against the railroads based on the 
price differential between short haul and long haul that could not be justified on the basis of costs (Kanazawa and Noll, 1994).

Although there were complaints throughout the United States, dissatisfaction with the monopoly abuses exercised by the railroads first took a more active form in the Midwestern states (McLean, 1900b, p.354). As a consequence of the effort of the organized agricultural class, in the early 1870s the states of Illinois, Minnesota, Wisconsin and lowa passed laws to regulate railroads. Such laws became known as "Granger laws".

It is important to highlight that the organized agricultural class was not restricted to the Granger movement. Following Buck (1913, p.158), this paper uses the term "Granger laws" to refer to the laws adopted in the early 1870 s that sought to constrain the railroads as a result of the effort of the organized agricultural class. Thus, this term does not limit itself to the laws of 1873 and 1874, which were passed under the direct influence of the Granger movement, but also covers the previous laws, which resulted from other types of farmer organization efforts. One example is the influence of the Legislative Farmers' Club in the adoption of the 1871 laws in the state of Illinois (Buck, 1913, p.144). Indeed, the campaign for the regulation of railroads began before the Granger movement gained importance. This evidence, however, does not minimize the importance of this movement.

The main laws passed at this time to constrain the railway - the Granger laws - as well as the reaction of the railroad companies are described in the subsections that follow.

\section{The Gronger Low ${ }^{5}$}

In 1870, the population of the state of Illinois, under the influence of farmers' claims, approved a new constitution that declared railways and warehouses as public goods subject to the rules and regulations prescribed by the law. In its provisions, the new constitution determined that the state legislature should approve laws fixing maximum rates, correct abuses and prevent unjust tariff discrimination in passenger and cargo transportation in the various state railways.

Thus, to meet the resolutions of the new constitution and under the influence of the Legislative Farmers' Club in 1871, the state legislature of Illinois passed laws regulating the railroads and grain warehouses. Among the laws passed were the following: a law that established maximum charges for passenger transportation within the state; a law that prevented unfair price discrimination and the charge of abusive prices in freight rates; a law that established maximum prices for grain storage; and a law creating a Railroad and Warehouse Commission. This commission was composed of three delegates appointed by the governor for a two-year term. Its function was to supervise railroads and warehouses; among its tasks were the determination of the format of the reports that the railroad companies should deliver annually and the 
examination of the conditions and management of the railroads regarding security and public accommodation. The information collected by the commission was to be presented to the governor in an annual report.

Although these laws passed in 1871 responded to the farmers' demands, the provisions for the enforcement of the various acts differed considerably from each other and were, in general, inadequate and sometimes inexistent. Thus, in 1873, with the agricultural class much better organized due to the growth of the Granger movement and of farmers' clubs throughout the state, there was a strong demand for the enforcement of the legislation of 1871 as well as for the enactment of additional and more rigorous laws.

In February 1873, however, the 1871 law that condemned the charging of abusive prices and the practice of unfair price discrimination was declared unconstitutional due to specification problems. In fact, this law condemned all forms of discrimination, not just those deemed unfair, and thus did not allow the railroads to practice price discrimination under any circumstances. This fact mobilized farmers and culminated in the adoption of another law to control the railroads in May 1873. The new law, which repealed and superseded the laws of 1871, corrected several flaws in its predecessors, such as the need for the specification of "unfair discrimination" and the assignment of punishments in case of violations. However, the most important change introduced by the law of 1873 was to assign to the state commission the task of establishing a schedule of maximum fares to be charged by each railroad, creating the first regulatory agency with power to regulate rates.

In Minnesota, the trajectory was similar. In this state, given the public demand to protect local producers, a law was passed in 1871 that set maximum tariffs for passengers and cargo transportation within the state. This law, however, was not put in place, which increased the demand for effective control of the state over the railroads. In 1874, with the triumph of the Granger movement in state legislative elections, a new law was passed based on the Illinois law of 1873 and established a state commission responsible for the determination of maximum rates.

In Wisconsin, the Granger movement pressure resulted in the passage in 1874 of two laws that sought to constrain the railroads. The first law, called Potter law ${ }^{6}$, fixed maximum levels for rail charges. This law was much contested because the rates it established were far below those that had prevailed previously in this state. The Potter law divided the railway lines in the state into classes and fixed for each class a ceiling for passenger fares. Regarding freight charges, the products being carried were divided into classes and the fixing of maximum tariffs took into account both the railway class and the product class. In addition, this law created a state commission that had the power to reduce tariffs and reclassify freight products. The second law, which became known as the anti-pass law, prohibited unfair price discrimination, the merger of parallel or competing railroads, and the issuing of free passes to state officials, judges and members of the legislative assembly. 
Finally, the state of lowa, under the influence of the Granger movement, also passed a law which set tariff ceilings for rail fares in 1874. The lowa law of railroads contained detailed and elaborated schedules for the establishment of maximum fares.

\section{The Reaction of the Railroad Companies and the Move to Federal Regulation}

In general, all the laws described above, both those that directly fixed rate ceilings as well as those that established commissions with the task of doing so, faced strong opposition from the railroad companies. They resorted to the courts to challenge the laws under the argument that the regulation expropriated its invested capital. In addition, they sought to make the legislation unpopular by making it seem contrary to state interests. The main argument in this regard was that the laws would have the effect of halting the expansion of the rail network (Buck, 1913).

The lawsuits filed by the railroads were taken to the Supreme Court. The first case to be tried involved the warehouse firm of Chicago Munn and Scott and the state of Illinois and arose from the refusal of the first to comply with the law that regulated the warehouses passed in 1871 (Buck, 1913, p.143). In its decision in 1877, the Court ruled the 1871 law of warehouses constitutional, validating the regulation of warehouse tariffs by the state of Illinois.

This 1877 decision in the Munn vs. Illinois case was a milestone for the economic regulation by the State (Viscusi et ali, 2005, p.363). Previously, the main argument against state economic regulation was based on provisions of both the state and federal constitutions that protected the sanctity of contracts. In addition, in the Munn case, companies also argued that the state regulation violated the Fourteenth Amendment to the federal constitution, which prevented the states from depriving any person of life, liberty or property without due process of law. However, in this case, the Court ruled that restrictions on the use of property covered by public interest were not prohibited by the Fourteenth Amendment and therefore could be regulated by state statutes (Kanazawa and Noll, 1994, p.17).

As the law that regulated grain warehouses was part of the "package" of regulatory laws passed in 1871, the legal challenge to the constitutionality of the regulation of railways was rejected by the court immediately after the Munn case. In the case of railroads, the court declared that the regulation was acceptable except in cases where the operating license explicitly exempted it, which proved not to exist in any case (Kitch and Bowler, 1979, p.343). Therefore, these decisions also reversed the precedent that the states should reserve in their licenses the right to change them or they would have to live with them forever (Kanazawa and Noll, 1994, p.17)

However, despite this final legitimation by the Supreme Court in 1887, the political power of the railroads and their complaint that the Granger laws contributed to the difficult situation in which they found themselves after the depression of 1873 severely 
weakened efforts to regulate the railroads in the late 1870 (Sanders, 1999 p.183). At this time, in three of the Granger states - Minnesota, Wisconsin and lowa - the laws were already repealed or weakened. In Minnesota, the state legislature replaced the law of 1874, which had created a commission with power to establish maximum rates, with a decree in 1875 that put a single official in charge of supervising the railroads and merely forbade price discrimination and the charging of exorbitant prices in passengers and cargo transportation. Similarly, the Potter law in Wisconsin, passed in 1874 and known to be the most severe of the Granger laws, was repealed in 1876 (Detrick, 1903). In lowa, the law passed in 1874 that established maximum rail fares remained in force longer than similar laws passed in other states but was repealed in 1878 and replaced by the creation of the first regulatory commission in this state, one which had only supervisory powers (Buck, 1913, p.178).

The Granger laws of the state of Illinois, however, although also challenged by the railroads, were not revoked and became an example for many states west of the Mississippi. Thus, through the law passed in 1873, Illinois became the first state to establish a permanent economic regulatory agency (Kanazawa and Noll, 1994). This law was considered to be an advance in the regulation of tariffs because it provided a more flexible solution than the attempts to establish maximum rates through direct legislation (Buck, 1913, p.149).

From the above, it follows that the process of institutional change that gave rise to regulatory agencies can be divided into two stages. The first step was the adoption of the 1871 laws in the state of Illinois, which fixed rate ceilings and created a commission to oversee railroads and warehouses. The second stage occurred when the laws of 1871 were replaced by the law of 1873 , which assigned to the commission the task of fixing the maximum charges.

Finally, it is worth highlighting the coexistence of two models of agencies in the late nineteenth century in the United States. As mentioned earlier, before the creation of the Illinois commission, in some eastern states, agencies existed that monitored the railroads to ensure public safety. Among these agencies the Massachusetts commission created in 1869 stood out. In addition to supervision, it had the power to arbitrate disputes involving the railroads and to advise on rates. This commission was to become a standard for the eastern states. On the other hand, the Illinois commission became a standard among the midwestern and southern states (Clark, 1891, p.39). In addition to the supervisory and arbitration ${ }^{7}$ functions, this commission had the power to fix rates (McLean, 1900b, p.368). Thus, the main difference between the typical agencies in the Midwest, such as the Illinois Commission, and those typical in the east, such as the one in Massachusetts, is that the first had the power to fix rates while the second could only indicate maximum rates that it considered fair.

McLean (1900b) refers to the eastern agencies as "advisory" or "weak" and Clark (1891) calls them "supervisory". The western agencies, in turn, are labeled "strong" agencies by McLean (1900b) and "regulative" agencies by Clark (1891). The table 
below, which is based on Clark (1891), groups the states based on the functions of the state agency in the year 1891. The numbers in brackets indicate the year of creation of the first agency in that state.

TABLE 1: Functions of State Agencies in 1891

\begin{tabular}{|c|c|c|c|}
\hline GROUP 1 & GROUP 2 & GROUP 3 & GROUP 4 \\
\hline $\begin{array}{l}\text { Supervision and } \\
\text { Advice }\end{array}$ & $\begin{array}{l}\text { Supervision, Advice } \\
\text { and Regulation }\end{array}$ & $\begin{array}{l}\text { Assessment for } \\
\text { Taxation }\end{array}$ & $\begin{array}{l}\text { No Railroad } \\
\text { Commission }\end{array}$ \\
\hline $\begin{array}{c}\text { Massachusetts (1869) } \\
\text { Connecticut }(1853) \\
\text { Vermont }\left(1855^{\circ}\right) \\
\text { Maine }(1858) \\
\text { New York }(1882) \\
\text { Ohio }(1867) \\
\text { Rhode Island }(1872) \\
\text { Michigan }(1873) \\
\text { Wisconsin }\left(1874^{9}\right) \\
\text { Virginia (1877) } \\
\text { Kentucky }(1882) \\
\text { Arizona (1891) } \\
\text { Colorado (1885) }\end{array}$ & $\begin{array}{c}\text { Illinois }(1871) \\
\text { lowa }(1878) \\
\text { Minnesota }(1874) \\
\text { Kansas }(1883) \\
\text { Missouri }(1875) \\
\text { California }(1876) \\
\text { Alabama }(1881) \\
\text { Georgia }(1879) \\
\text { South Carolina (1881) } \\
\text { Mississippi }(1884) \\
\text { New Hampshire }(1844) \\
\text { North Dakota }\left(1885^{10}\right) \\
\text { South Dakota }\left(1885^{11}\right) \\
\text { Oregon }(1887) \\
\text { Texas }(1891) \\
\text { Nebraska }(1885) \\
\text { North Carolina }(1891)\end{array}$ & $\begin{array}{c}\text { Arkansas (1881) } \\
\text { New Jersey (1873) } \\
\text { Indiana (1881) }\end{array}$ & $\begin{array}{l}\text { West Virginia } \\
\text { Maryland } \\
\text { Delaware } \\
\text { Louisiana } \\
\text { Nevada } \\
\text { Montana } \\
\text { Washington } \\
\text { Idaho } \\
\text { Wyoming } \\
\text { Utah } \\
\text { New Mexico } \\
\text { Indiana } \\
\text { Oklahoma } \\
\text { Florida }{ }^{12} \\
\text { Tennessee }^{13}\end{array}$ \\
\hline
\end{tabular}

Source: Clark (1891)

The state of Pennsylvania had, in 1891, a commission with the function of collecting statistics. Its first commission was established in 1874.

Despite the difference between the eastern and western models of commissions ${ }^{14}$, both had in common the opposition of the railroads. Nevertheless, this feeling of hostility by the railroads was gradually moderated after the Supreme Court decision that confirmed the constitutionality of rate regulation (Buck, 1913, p.152). In this sense, according to McLean (1900b, p.368), slowly, the commissions that performed continuous policies positioned themselves as impartial tribunals concerned with the interests of both parties and, with the mediating power exercised through agreements, they were able to prevent the aggravation of disputes. Indeed, by performing these functions and providing information on the railroad business to the public, the commissions brought about a more harmonious relationship between the public and the railroads. According to McLean, one of the most important services provided by the commissions was the enforcing to the public of the limits of the competitive principle in the railroad business.

The rate regulation exerted by the Illinois commission, however, was weakened with the Supreme Court's 1886 decision in Wabash, St. Louis and the Pacific Railroad Co. $v$ Illinois case. In this decision, the Court held that the state of Illinois could not regulate the rates of a commercial activity extending beyond its borders because this would violate the constitutional prohibition of state interference in interstate commerce. Therefore, this decision prevented the states from correcting the price differential 
between short and long hauls, as they could no longer regulate the prices in longdistance routes. Accordingly, the Wabash decision, as it became known, provided an additional political incentive for the establishment of federal regulation some months later, through the passage of the Interstate Commerce Act (Kanazawa and Noll, 1994, p.18) and the creation of the Interstate Commerce Commission ${ }^{15}$ in the following year.

\section{ANALYSIS AND CONCLUSION}

From the historical survey presented above, it follows that the distributional conflict between farmers and railroads is key to explaining the process of institutional change that led to the creation of regulatory agencies.

In the early 1870s, farmers who were unsatisfied with monopoly abuses by the railroads sought government intervention to contain them. This demand gained force with the rise of farmers' organizations, particularly the Granger movement, leading several states in the Midwest to adopt measures that sought to constrain the railroads. Amid this agitation, in 1871, the state of Illinois adopted laws that fixed rate ceilings and created a commission in charge of supervising railroads and warehouses. When the enforcement provisions in these laws proved inadequate, the mobilization of farmers continued and culminated in the adoption of a new law to control the railroads in 1873. By assigning to the commission the task of fixing maximum prices, this law of 1873 gave rise to an institutional model of regulatory agencies.

Hence, the process of institutional change that led to the regulatory agencies can be divided into two stages. The first stage took place with the adoption of the laws of 1871 in the state of Illinois, which fixed tariff ceilings and created a commission to supervise railroads and warehouses. The second stage occurred when these laws of 1871 were replaced by the law of 1873 , which assigned to the commission the task of establishing maximum charges.

In the framework of North's (1990) theory, both stages of the institutional change process that led to the rise of the agencies consisted of formal processes of institutional change, since agents turned to the political process to change the rules in force. Thus, such steps required a considerable investment of resources.

The main motivation for the mobilization of farmers was their perception as losers in economic exchanges with railroads in the existing relative price structure. While this perception would not necessarily have to be related to objective facts, certainly the price discrimination practices employed by the railroads were fundamental to its development. Hence, the farmers based on estimates of costs and benefits decided to use the political process to change the rules in force. Furthermore, they also considered it advantageous to devote resources to an intermediary organization, in this case the Granger movement, to realize the potential gains of the political change. 
North in a brief illustrative comment supports this analysis:

[the legislative enactments of Greenback, Granger and Populist movements of the U.S. farmers] reflects farmers' persistent beliefs that they were being wronged by monetary policies, railroads, grain elevators, bankers, and others. They acted on these convictions by forming organizations with the objective of enacting corrective legislation first in state legislatures, then through the Populist party and the Democratic party in the U.S. Congress. (North, 1990, p.44)

Therefore, it appears that North's (1990) theory fits well in explaining the institutional change process that gave rise to the regulatory agencies. This is so because the perception on relative prices underlined by this author as the main motivation for institutional change was effectively the major factor behind the emergence of these agencies.

Finally, it is important to highlight that understanding the process that gave rise to the first regulatory agencies is crucial to the comprehension of its evolution. As North (1990) argues, history matters because the continuity of society's institutions connects the past to the present and the future.

\footnotetext{
Notes

${ }^{1}$ As North's thinking changed over time, this section considers the institutional change theory presented in his best known work, the book "Institutions, Institutional Change and Economic Performance" (North, 1990). For more details about the evolution of North's view regarding institutional change, see Carvalho (2012). Fiani (2003) and Gala (2003) report the evolution of North's thinking more generally.

${ }^{2}$ In the article "Institutional Change: A Framework of Analysis"from 1993, which according to North himself is based on the book "Institutions, Institutional Change and Economic Performance" from 1990, North exposes more clearly his reasoning about the sources of institutional change, undoing the ambiguities shown in the book. For further details on these ambiguities, see Carvalho (2012).

3 The Midwest comprises the states of Michigan, Ohio, Indiana, Illinois, Wisconsin, Minnesota, lowa, Missouri, North Dakota, South Dakota, Nebraska and Kansas.

${ }^{4}$ For example, the movement sought to introduce cooperation schemes among farmers for the purchase of inputs, marketing of agricultural products, insurance, and even for the manufacture of agricultural tools (Buck, 1913, p.52).

${ }^{5}$ The account of these laws presented here is based on a comprehensive description of that legislation reported in Buck (1913).

${ }^{6}$ The law was so named because its bill was initially introduced by Senator Potter.

7 The arbitration function was spontaneously incorporated in 1877 as a result of a more comprehensive appreciation of the commission's responsibilities to the railroads and the public (McLean, 1900b, p.368).

${ }^{8}$ Composed of only one commissioner.

${ }^{9}$ Created under the Potter law.

${ }^{10}$ Territorial Commission.

11 Territorial Commission.

${ }^{12}$ Abolished in 1891.

${ }^{13}$ Abolished in 1885 .

${ }^{14}$ For more details about the differences between the two models of commission, see Carvalho (2012).

${ }^{15}$ Initially, the federal commission was not empowered to fix rates. Only after the passage of the Hepburn Act in 1906, the ICC was authorized to set maximum rates.
} 


\section{REFERENCES}

ADAMS, C. "Railroads: Their Origin and Problems". Nova York: G.P. Putnam's Sons, 1878.

BUCK, S. "The Granger Movement: A Study of Agricultural Organization and Its Political, Economic and Social Manifestations, 1870-1880". Cambridge: Harvard University Press, 1913.

CARVALHO, P. "A Origem das Agências Reguladoras nos Estados Unidos no Século XIX: Uma Aplicação das Teorias de Mudança Institucional de Jack Knight e Douglass North". Dissertação de Mestrado. Rio de Janeiro: IE/UFRJ, 2012.

CLARK, F. "State Railroad Commissions and How They May be Made Effective". Publications of the American Economic Association, vol. 6, n 6, 1891.

DETRICK, C. "The Effects of the Granger Acts". Journal of Political Economy, vol. 11, n², 1903.

DOWD, D e DOBBIN, F. "Origins of the Myth of Neoliberalism: Regulation in the First Century of US Railroading". In Magnusson, L. e Ottosson, J. (ed.) The State, Regulation and the Economy: An Historical Perspective. Northampton: Edward Elgar, 2001.

FIANI, R. "Estado e Economia no Institucionalismo de Douglass North". Revista de Economia Política, vol. 23, n² 2 (90), 2003.

FIANI, R. "Cooperação e Conflito: Instituições e Desenvolvimento Econômico". Rio de Janeiro: Elsevier, 2011.

GALA, P. "A Teoria Institucional de Douglass North". Revista de Economia Política, vol. 23, n 2, 2003.

KANAZAWA, M. and NOLL, R. "The Origins of State Railroad Regulation: The Illinois Constitution of 1870". In Goldin, C. e Libecap, G. (ed.) The Regulated Economy: A Historical Approach to Political Economy. Chicago: The University of Chicago Press, 1994.

KITCH, E. and BOWLER, C. "The Facts of Munn v. Illinois". Supreme Court Review, 1979.

MCLEAN, S. "Federal Regulation of Railways in the United States". The Economic Journal, vol. 10, n० 38, 1900a.

MCLEAN, S. "State Regulation of Railways in the United States". The Economic Journal, vol. 10, nº 39, 1900b.

NORTH, D. "Institutions, Institutional Change and Economic Performance". Cambridge: Cambridge University Press, 1990.

NORTH, D. "Institutional Change: A Framework of Analysis". In Sjöstrand, S. (ed.) Institutional Change: Theory and Empirical Findings. New York: M.E. Sharpe, 1993.

SANDERS, E. "Roots of Reform: Farmers, Workers and the American State: 1877-1917". Chicago: The University of Chicago Press, 1999.

VISCUSI, W. HARRINGTON, J. and VERNON, J. "Economics of Regulation and Antitrust".

Cambridge: MIT Press, 2005.

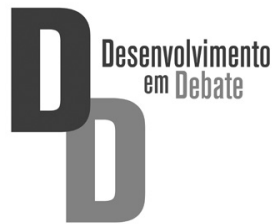

